\title{
An evaluation methodology for the tangible and intangible assets of city-regions: the $6 \mathrm{~K} 1 \mathrm{C}$ framework
}

\author{
Koray Velibeyoglu \\ Department of City and Regional Planning, \\ Izmir Institute of Technology, \\ Urla, 35430 Izmir, Turkey \\ E-mail: korayvelibeyoglu@iyte.edu.tr
}

\author{
Tan Yigitcanlar* \\ School of Urban Development, \\ Queensland University of Technology, \\ Brisbane, Qld 4001 Australia \\ E-mail: tan.yigitcanlar@qut.edu.au \\ *Corresponding author
}

\begin{abstract}
Together with hard and soft networks, tangible and intangible regional assets play an important role in the knowledge-based development of competing city-regions. The aim of this paper, therefore, is to investigate the best ways of managing invaluable tangible and intangible assets of city-regions. The paper explores the importance of asset management of city-regions by giving special emphasis on their knowledge asset base. This paper develops and introduces a theoretical framework to conceptualise a new approach to articulate the strategic planning mechanism, so called the $6 \mathrm{~K} 1 \mathrm{C}$ framework. The $6 \mathrm{~K} 1 \mathrm{C}$ framework is part of the strategic planning process of continuous improvement of overall public sector performance. The framework provides a proactive check-list approach integrated for managing and harnessing tangible and intangible assets of the post-industrial city-regions.
\end{abstract}

Keywords: knowledge-based urban development; KBUD; strategic planning; tangible assets; intangible assets; capital systems; asset management; city-regions.

Reference to this paper should be made as follows: Velibeyoglu, K. and Yigitcanlar, T. (2010) 'An evaluation methodology for the tangible and intangible assets of city-regions: the 6K1C framework', Int. J. Services Technology and Management, Vol. 14, No. 4, pp.343-359.

Biographical notes: Koray Velibeyoglu is an Assistant Professor in Urban and Regional Planning at the Izmir Institute of Technology in Turkey. His research interest focuses on urban information and communication technology, urban policy-making and knowledge-based development processes. Particularly, he is an expert in understanding networked urbanism and the impacts at the metropolitan and local level and the role of information and communication technologies in sustainable urban development. He is an International Advisory and Review Board member of the International Journal of Knowledge Based Development. 
Tan Yigitcanlar is a Senior Lecturer in Urban and Regional Planning at the Queensland University of Technology in Australia. He has a multi-disciplinary background and extensive work experience in private consulting, government and academia. The focus of his research is promoting knowledge-based and sustainable urban development. He has been responsible for a wide variety of teaching, training and capacity building programmes on urban planning, environmental science, policy analysis and information and communication technologies in Turkish, Japanese and Australian universities. $\mathrm{He}$ is the Editor-in-Chief of the International Journal of Knowledge Based Development.

\section{Introduction}

Throughout the last two centuries, social production had been primarily understood and shaped by the neo-classical economic thought that recognised land, labour and capital as the three primary factors of production. Neo-classical economics considered knowledge, education and intellectual capital as secondary, if not incidental, parameters of production. During the last several decades, however, it has become apparent that knowledge in and of itself is sufficiently important to deserve recognition as a primary factor of production. Similarly, intellectual capital is also recognised by firms and local governments as one of the vital sources of competition in urban and economic development within the knowledge-based economy. Since then many city-regions around the world started to view knowledge and creativity as keys to development and economic prosperity and adjusted their endogenous development strategies increasingly by visioning an ultimate goal of knowledge-based development (Knight, 1995, 2008).

In this context, knowledge-based urban development (KBUD), a strategic management approach applicable to human settlements, has gained popularity as a powerful strategy for sustainable economic, social and urban growth, and for the post-industrial development of city-regions (Yigitcanlar et al., 2008b). In the knowledge-based development process of city-regions, knowledge-based assets play a critical role by both securing a competitive advantage in the knowledge-based economy and also engineering the formation of creative urban regions (Boisot, 1999; Yigitcanlar et al., 2008c). KBUD is a mechanism to reorganise critical tangible and intangible assets and networks of city-regions. However, to date KBUD has not yet been fully operationalised as it is still in its early developmental stage.

The aim of this paper is to investigate the best ways of managing city-regions' strategic tangible and intangible assets while pursuing a KBUD that is sustainable and competitive. To realise this aim the paper develops a framework entitled the $6 \mathrm{~K} 1 \mathrm{C}$ framework to be used in the testing of city-regions' tangible and intangible assets. This paper examines and discusses KBUD mechanisms and the importance of asset base of city-regions since they are among the key attributes of competing city-regions. The study also provides a research agenda to conceptualise the $6 \mathrm{~K} 1 \mathrm{C}$ framework and to examine the ways of assessing city-regions' tangible and intangible knowledge asset base. 


\section{City-regions and their KBUD}

Friedmann (2002, p.22) defines a 'city-region' as "a functionally integrated area consisted of both a large urban core and a contiguous region that serves to city's multiple needs and provides a space for its expansion". Within a city-region the distinction between urban and rural is not much meaningful as it establishes a new form of urban landscape. Characteristics of a city-region are mainly determined by its geographical size, commuting time and complex form of governance. Geographical size of a city-region is not only determined by the administrative area of the city, but also in many cases its impact on a larger hinterland establishes its boundary. Commuting time and distance is a way of defining the limits of a city-region. For example, if in a rural area or town majority of people travel into a particular city for work, then it can be said that this area is residing in the city-region. Additionally, the multiplicity of governance levels outlines the overlapping of the various jurisdictional boundaries of governmental and administrative units of a city-region (Friedmann, 2002).

As Scott et al. (2001) suggest that in the process of globalisation a notion of global city-region has arrived, which is based on dense nodes of regional social formations. As an emerging political-economic unit, global city-regions have distinguished beyond the national boundaries of states with their increasing autonomy of action in global knowledge-based economy. Considered as by-product of globalisation, city-regions constitute the basic economic powerhouse of the world economy. In other words, globalisation and city-region development are two faces of a single integrated reality: on the one hand, there are severe pressures of the global markets; on the other, city-regions have far and wide strong incentives to sustain and increase their competitive economic advantages within the regional collective order (Vigar et al., 2005).

There are more than 300 city-regions around the world today with populations greater than a million. They range from a metropolitan agglomeration dominated by a strongly developed core such as London region, to more polycentric geographic units as in the case of Randstad (The Netherlands) and Emilia-Romagna (Italy). The competition between city-regions has been intensified since information and communication technologies (ICTs), rapid transport connections and lower transport costs enabled a real-time global market. Tough global competition pushes city-regions to define their roles within the global processes and to develop niche market areas to excel (Carrillo, 2006). City-regions, to compete nationally and internationally, need knowledge infrastructures; a concentration of well-educated people; technological, mainly electronic, infrastructure and connections to the global knowledge-based economy (Yigitcanlar et al., 2008d).

Being competitive and achieving sustainable mode of development stands critical in ahead of the rising city-regions of the world today. Competitiveness is a key value that has globally been pumped by neo-liberalism with the motto of 'compete or perish'. The competition, as Friedmann (2006) underlines, is not for attracting consumers but for attracting national and international investors and workers to city-regions to secure their global position in the new economy. Besides many promises, such as global recognition and wealth generation, the notion of competing city-regions has some dead-ends in sustaining a continuous accumulation of growth and wealth that are heavily based on 
exogenous global capital (Scott, 2000). The logic of global competition dictates that "global capital is footloose, has no loyalty to place and its horizon of expectation is short: investments have to be recouped within only a few years" [Friedmann, (2006), p.4]. In terms of city-regions, the real danger is the mobility of global capital that once capital moves on to a more lucrative location, what it leaves behind is a degraded city-region that has lost its major economic base as well as sustainable endogenous development opportunities.

On the social front, city-regions in all parts of the world have been experiencing tremendous internal breakdowns, both directly and indirectly, as a result of globalisation and the development of new forms and methods of production (Scott et al., 2001). The utmost important issues are income inequality, unemployment, social and spatial fragmentation, sub-standard living areas in urban core after deindustrialisation of urban economies in first world city-regions, lack of social policies for the increasing urban poor and so on. In city-regions of developing countries, especially in China and India, these pressures are even more severe. Furthermore, as Friedmann (2005) argues, in the case of booming cities of developing countries, the leitmotiv of economic progress is 'growth at all cost' meaning a lower chance for social and ecological sustainability. Post-industrial societies of North America and Europe, however, demanding to promote 'quality of life' as a basic driver of sound public policy actions. This view assumes that city-regions are not only sites of economic competitiveness, but also places where the notion of quality of life takes place (McCann, 2007).

In terms of governance many city-regions has very hard to be integrated since the different governmental units often act at cross purposes. City-regions are open to multiple influences from international players (i.e., World Bank) to the nation state; intergovernmental institutions operating at different levels to specialised authorities to carry out specific functions (i.e., regional transportation) local governments to private sector enterprises (i.e., real estate developers and industrialists) and non-governmental organisations (Friedmann, 2002). Problems of integrated management and service integrity among those stakeholders contribute to the organisation and management of city-regional territories. In 'Northern way' (the UK), for instance, different local government bodies integrated to form spatial coalitions in search of effective bases from which to deal with both the threats and the opportunities of globalisation (Jonas and Ward, 2007).

The most challenging issue for booming city-regions is to achieve sustainable development that have raised the importance of emerging environmental agenda focuses on the maintenance and improvement of quality of life. During the last couple of decades, sustainable urban development has become a crucial and widely pronounced concept, covering all economic, environmental, cultural and social objectives of city-regions (Jabareen, 2006). In terms of economic sustainability this means that "the ability to generate wealth and resources and, for the moment, as the planet is now entirely capitalist and will be so for the foreseeable future, it also means the ability to create wealth by increasing productivity and increasing competitiveness of the city in a market environment" [Castells, (2000a), p.119]. In a knowledge-based economy, connectivity of global linkages and renewal of human resources for creating added value play a key role in achieving economic sustainability. Other components of urban, social and ecological sustainability are equally important for the formation of a knowledge society. Knowledge society is an integral element of a knowledge-based economy, therefore, rather than solely investing on economy, investing on communities, via social and human 
development programs, helps them to become sustainable communities and also helps in the construction of a strong economic base for cities. In social terms, urban sustainability includes acknowledgement of social heterogeneity, inclusion, tolerance, public participation and democratic governance (Castells, 2000a). Although natural environment has always been a necessary precondition for capital accumulation, the importance of ecological sustainability could only be fully appreciated in recent years followed by the warnings of environmental catastrophes (While et al., 2004). Besides, social and ecological sustainability have strong relations with the foundation stones of the knowledge-based city formation, i.e., urban diversity, quality of life, social equity, sustainable communities and preserved natural environment (Van Winden and Berg, 2004; Yigitcanlar et al., 2008a).

To exacerbate the growing needs and problems of city-regions a more orderly and progressive form of urban development is needed. As an emerging field of study and practice, KBUD can be considered as an integrated way of approaching city-regions via strategic actions guided by the knowledge production and their reflection on the urban form (Yigitcanlar and Velibeyoglu, 2008). KBUD is considered as a knowledge-intensive strategic development approach in the tough global economic competition (Yigitcanlar et al., 2008b). KBUD involves contemporary understanding and management of value dynamics, capital systems, urban governance, development and planning. The main promise of KBUD is a secure economy in a human setting, in short, sustainable urban and economic development. KBUD transcends many areas of economic and social policy and has three broad purposes (Figure 1).

Figure 1 Three pillars of KBUD (see online version for colours)

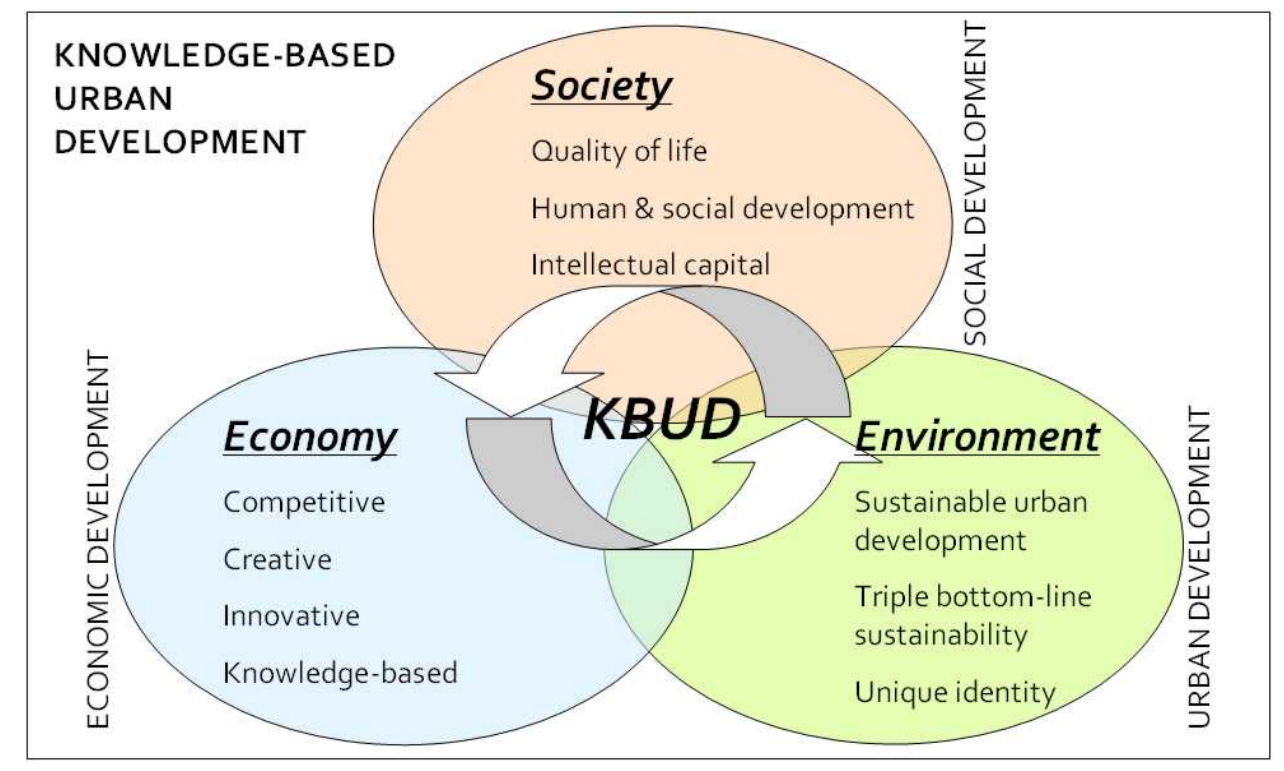

Source: Yigitcanlar (2008, p.308)

Firstly, it is an economic development strategy that codifies technical knowledge for the innovation of products and services, market knowledge for understanding changes in the economy, financial knowledge to measure the inputs and outputs of production and 
development processes and human knowledge in the form of skills and creativity, within an economic model (Lever, 2002). Secondly, it indicates the intention to increase the skills and knowledge of residents as a means for human and social development (Gonzalez et. al., 2005). Thirdly, it builds a strong spatial relationship among urban development clusters to augment the knowledge spill-over effect that contributes significantly to the engineering of creative urban regions (Yigitcanlar et al., 2008a). Common broad KBUD policies include: developing financial, social and human capital systems, distributing instrumental capital, developing and adopting the state of art technologies, providing hard and soft infrastructures and providing quality life and place (Carrillo, 2004; Yigitcanlar et al., 2008b).

\section{Understanding the asset base of city-regions}

An asset literally means a person, physical structure or place, business, service or other accessible resource used by local residents for their personal, social, economic or cultural needs and benefits (Ford, 2004). Common characteristics of assets can be defined as below:

- Economic dimension: Assets are resources with economic value that an individual, corporation or country owns or controls with the expectation that it will provide future benefits.

- Sustainability: Resources that we want to keep, build upon and sustain for future generations.

- Accumulation: A stock of financial, human, natural or social resources that can be acquired, developed, improved and transferred across generations. It generates flows or consumption, as well as additional stock (Moser, 2006).

Assets can be categorised under two main groups: financial and non-financial assets. The former includes stocks, bonds, bank deposits and a like. Financial assets do not necessarily have physical worth and therefore they can be treated as symbolic. The latter, however, has a physical value such as land, property or some type of object. Unlike financial assets they have values based upon their physical properties (ESA, 1995). Unlike non-financial assets, financial assets are short-lived, controlled by an entity, can easily be turned into money and investment and therefore measured objectively. Assets can also be classified as tangible and intangible. A tangible asset is an asset that has a physical form such as machinery, buildings and land. An intangible asset, however, is not physical in nature (Filipo, 1988). Corporate intellectual property (i.e., patents, trademarks, copyrights, business methodologies, service activities), goodwill and brand recognition are all common intangible assets in today's marketplace. The knowledge-based economy provides an opportunity for firms with limited tangible assets to command high market values if they invest on valuable intangible assets (Malhotra, 2003; Kaplan and Norton, 2004). E-business firms like Amazon, Google and Facebook are good among the examples as they mainly hold a rich source of human and intellectual capital.

Tangible and intangible assets could be used interrelated to each other in order to produce better results for future developments. For example, in leisure service settings, 
the tangible, physical environment plays a critical role on the overall perceptions of intangible service quality (Wakefield and Bloggett, 1999). Similarly, city-regions are unsustainable and uncompetitive without a solid base of strategic tangible and intangible assets. Friedmann (2006) distinguishes seven clusters of tangible and intangible assets for the long-term endogenous development of city-regions:

- Human assets: Including people and quality of their lives and places.

- Social assets: Referring to city-region's quality of social capital and distinctive organisational capacities of civic institutions.

- Heritage and cultural assets: Covering preservation of historically-significant built environment and distinctiveness and vibrancy of its cultural life.

- Natural assets: Referring to city-regions' critical natural amenities and resources that are more fragile to speculative urban development.

- Environmental assets: Covering qualities of city-regions' physical environment that are essential for sustaining life.

- Infrastructural assets: Referring to all basic facilities and services for transportation, energy, communications, water supply, sewerage and solid waste disposal, and health, education and cultural infrastructure and services.

- Intellectual capital or knowledge assets: Referring to city-regions' quality of knowledge resources and institutions.

Figure 2 Relationship between asset categories and capital systems

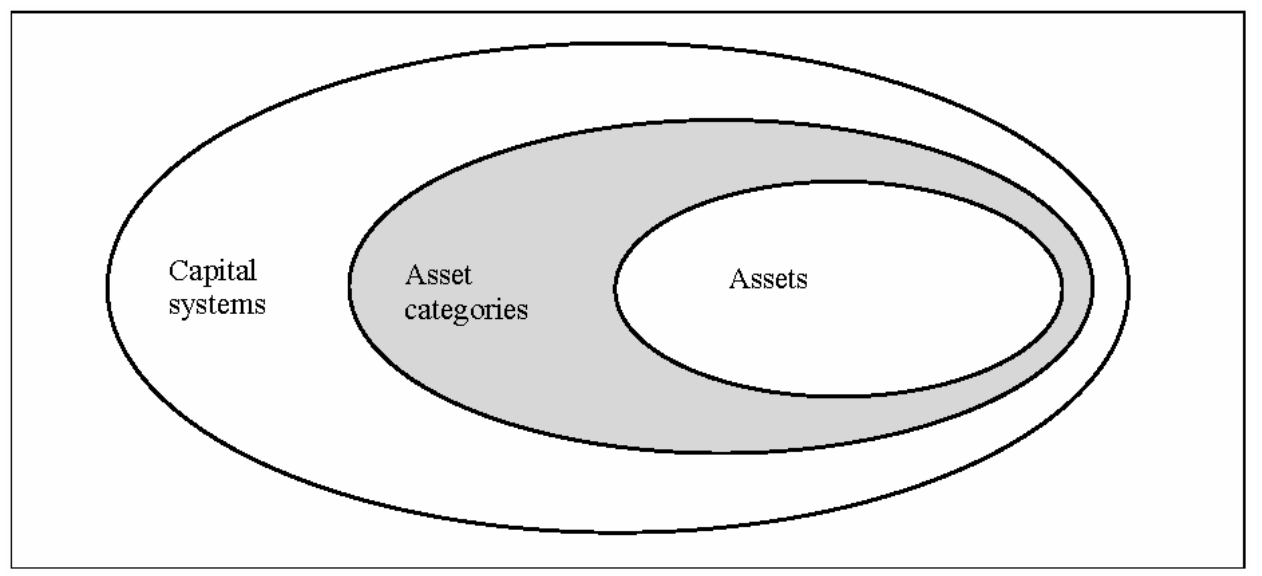

An asset or category of assets can be clarified in the form of 'capital' and 'capital systems' (Figure 2). Seeing cities as complex capital systems is useful to analyse basic economic, social and institutional production systems and value development and assessment practices (Carrillo, 2004). The capital systems approach is successfully applied by the World Capital Institute and Teleos in the context of MAKCI (Most Admired Knowledge City) study. They used a set of capital categories (including identity capital, intelligence capital, financial capital, relational capital, human individual capital, 
human collective capital, instrumental-material capital and instrumental knowledge capital) to gauge the world's best knowledge-based city. Capital systems methodology has a generic value base, which is possible to use it in non-productive organisations and regional and global settings. Known as a capital system, this taxonomy identifies the basic capital elements of productive systems and 'meta-capitals'. Each capital system is not productive on its own but significantly leveraging the system's overall capacity (The World Capital Institute and Teleos, 2007). In this study the reciprocal relationship between asset categories and capital systems are combined in the context of city-region's critical asset and capital bases (both tangible and intangible) (Table 1).

Table 1 Capital systems and assets of city-regions

\begin{tabular}{|c|c|c|}
\hline Capital systems & Asset categories & Assets \\
\hline Identity capital & Symbolic assets & $\begin{array}{l}\text { City brands, geographic trademarks } \\
\text { landmark buildings, endemic plants }\end{array}$ \\
\hline Social capital & Social assets & Civic initiatives, community centres \\
\hline Human capital & Human assets & $\begin{array}{l}\text { People's capacity and skills to work, } \\
\text { education and training centres, } \\
\text { thickness of labour market }\end{array}$ \\
\hline Cultural capital & $\begin{array}{l}\text { Heritage and cultural } \\
\text { assets }\end{array}$ & $\begin{array}{l}\text { Historical and archaeological sites, } \\
\text { handcrafts, cuisine, ethnography, } \\
\text { foreign language, openness and } \\
\text { tolerance }\end{array}$ \\
\hline Environmental capital & $\begin{array}{l}\text { Natural, environmental } \\
\text { and infrastructural assets }\end{array}$ & $\begin{array}{l}\text { Natural and constructed amenities, } \\
\text { flora and fauna technical } \\
\text { infrastructure }\end{array}$ \\
\hline Financial capital & Financial assets & $\begin{array}{l}\text { Financial institutions and resources } \\
\text { available to people }\end{array}$ \\
\hline Knowledge capital & Knowledge assets & $\begin{array}{l}\text { Intellectual property rights, brands, } \\
\text { research and development centres, } \\
\text { universities }\end{array}$ \\
\hline
\end{tabular}

Source: derived from Carillo (2002) and Friedmann (2006)

Although all of these seven categories of assets and capital systems have equal importance, particularly in recent years, knowledge assets have clearly become a desirable marketing instrument for knowledge-based cities. The primary reason behind this increasing importance is the role knowledge assets play in attracting investment and talent to city-regions (Reichert, 2006; Benneworth and Hospers, 2007). Knowledge assets represent the valuable source of a city-region's competences and capabilities that are deemed essential for economic growth, competitive advantage, human development and quality of life. It is vital for development organisations to understand the value of a city-regions' knowledge assets in advancing sustainable human development.

Despite of its abstract nature (Boisot, 1999) and intangibility (Malhotra, 2003), knowledge assets are largely stored and distributed unevenly among city-regions. In this regard, strengthening the knowledge asset base of city-regions requires strong knowledge clustering (e.g., universities, R\&D institutions, knowledge precincts), which is particularly important in the promotion of the spill-over effects found to be vital for long-term economic prosperity (Lever, 2002). In the following parts of the paper a theoretical research framework is introduced to test knowledge asset base of city-regions. 


\subsection{Managing tangible and intangible assets of city-regions}

Urban researchers frequently come across with two important questions of: Why managing asset base of city regions is important? How critical regional assets can be best managed to secure sustainable development and competitive economy in the long run? In the urban development context, assets are defined as popularly recognised attributes of city-regions. They are considered essential for the maintenance of urban life and vital for the sustainability of the environment, economy and society. Knowledge-based economy has created a new policy discourse that calls for more attention to coherent strategies to develop the assets and qualities of city-regions (Healey, 2005). In an asset-based approach, assets are viewed as the bases of solutions, and this approach has a stronger endogenous point of view in growth and development with a greater sustainability focus. The critical local assets of a city-region influence the potential success of development strategies. Managing the tangible (i.e., physical infrastructure and buildings such as transport, property, utilities and cultural amenities) and intangible assets (i.e., knowledge, trust, cooperation and creativity) contribute to the competitiveness of city-regions (Cities Alliance, 2007). In order to improve solid asset base of city-regions, a long-term asset building strategy and a careful asset management framework are needed to be developed and implemented. Integrated urban asset management would not only facilitate inter-sphere cooperative governance, but would also enable strategic urban planning and decision making. Generic steps of the asset management process (identification, valuation, planning, implementation and monitoring) are briefly explained below, as the process has offerings for the successful development of city-regions (US Department of Transportation, 1999).

- Asset identification: This step involves identification of asset base of individuals, associations, institutions and resources in the region. For comprehensive understanding of critical regional assets 'asset mapping', a simple but effective technique, is used to document the main tangible and intangible assets available for the local economy. In the local economic development context, it is most often applied at the community or small-size city level. Asset mapping is often conducted by using a participatory approach in which local stakeholders help identify, rank and prioritise different local assets. In some cases, it also involves assessing factors that may threaten and/or strengthen these assets and developing strategies to support and enhance them. As an analysis tool, the main strength of asset mapping is that it generally presents a positive outlook as it focuses on opportunities rather than problems. Asset mapping exercise addresses the definition of critical tangible and intangible assets and pillars of competitiveness of city-regions [Cities Alliance, (2007), p.104].

- Asset valuation: Asset valuation includes different qualitative (i.e., measuring collective sustainability, relational quality) and quantitative assessments (i.e., measuring economic value, service life, investment value) to value city regions' critical assets. By doing this decision-makers are informed about their functions for the region, their services they provide, the past condition and performance and current and predicted future condition.

- Asset management plan: Careful asset management planning is needed to preserve, maintain or improve identified and valued regional assets to ensure the maximum 
benefit to the public. In order to retain and flourish asset base of a city-region there need to be sound preservation, development and accumulation strategies prepared covering different scales and time periods. To mobilise the regional asset base implementation projects should be selected to best endow both competitiveness and sustainability of a city-region according to calculated risks and benefits. Asset management plans should also tackle with the creation of budgetary instruments and problems related to budget constraints and allocation of financial resources.

- Asset-based project implementations: In order to create best results, implementation criteria for selected asset-based projects should be determined. Recent implementations in Appalachia region of the USA, rural development projects of Carnegie Trust in the UK and Leaders program of European Union provides clues about the basic principles of the project implementation including: area based approach, bottom-up approach, innovation, networking and cooperation between areas, integrated with other plan, project and initiatives and capability of creating pool of knowledge resources to share experiences (ARC, 2004).

- Performance monitoring: To monitor the impact of project implementation and policy decisions are important to gain feedback and evaluate the results of asset management plans. According to monitoring of strategy plans and projects city-regions can adjust their decision-making framework and creation of future project selection and their implementation criteria.

\subsection{Challenges to asset-based development}

It is important for city-regions to clearly understand their own particular circumstances to build on what is already there in order to make the best use of their invaluable assets (Lee, 2008). At this point, mapping and investing on city-regions' tangible and intangible assets helps them to improve their endogenous development and creates a positive outlook in attracting exogenous investment and talent. However, for city-regions, such an approach simultaneously invites major challenges that impede sustainable development.

The first challenge is the emergence of a polarised city-region or a dual city-region. Asset-based development informed by ideas of recognition of tangible and intangible assets is, therefore, decidedly not a comprehensive approach. Asset-based development needs to be highly selective, focusing on the distinctive qualities and dynamics of particular regional assets. The city-region, then, becomes a highly selective collection of assets that requires most of the city-region's resources for the promotion of critical assets. This implicitly underlines that the privileged socio-economic groups (haves) gain the most in the process at a cost of the most disadvantaged ones (have-nots) becoming more vulnerable. This process can be best exemplified by the 'dual city' thesis of Castells (2000b) and rise of 'premium places' posed by Graham (2004).

The second challenge is the openness to external fragmentation. Investing on and building assets of a city-region usually takes long time and needs careful management to become sustainable. On the other hand, foreign investment uses, many cases consumes, directly the best assets of a region rather than investing on and caring of the valuable ones. As Friedmann (2006, p.12) states "global capital is highly mobile and not loyal to a region" and he continues "its eyes are principally on shareholder interests rather than on regional wealth creation... Seducing global capital by sacrificing regional assets leads only to an illusory development". 
The third challenge is the identification and management of city-region's critical tangible and intangible assets. Although the relative value of the assets may change from region to region, some are considered as critical like natural and heritage assets that take very long time to evolve, however, can easily be fragmented, destroyed and vanished through the thoughtless exploitation. Similarly city-region's intellectual and creative assets are highly mobile and hard to retain without making conscious policy efforts. Urban policy-makers are usually concerned with the visible and tangible dimensions of city-regions. But like new technologies (i.e., ICTs) critical intangible assets of city-regions (i.e., intellectual, cultural and creative assets) remain largely invisible and a big challenge for urban competitiveness and knowledge-based development of competing city-regions. For that reason, when assets are identified, their checking and supporting systems also need to be put in place to maintain and strengthen them. This requires strong governance, political leadership and vision, as well as a sound strategic planning approach that is knowledge-based.

\section{Evaluating the knowledge asset base of city regions: the 6K1C framework}

The research framework developed for this study is an attempt to articulate the planning and managerial issues of strategic planning and management of the tangible and intangible asset base. The framework assesses 'knowledge asset base' as an example to illustrate planning process under the $6 \mathrm{~K} 1 \mathrm{C}$ framework formulation, which is primarily a check-list system for the sustainable accumulation of tangible and intangible assets within city-regions. Figure 3 illustrates steps of a generic strategic planning process (Rowley et al, 1997), asset management (US Department of Transportation, 1999) and how the $6 \mathrm{~K} 1 \mathrm{C}$ framework relates with them.

The innovativeness of this research framework lays in the integration of the strategic planning process with the $6 \mathrm{~K} 1 \mathrm{C}$ framework, which forms a base for the KBUD strategies. The 6Ks (know-where, know-when, know-what, know-why, know-how, know-who) and 1C (control) is derived from the 5Ws (what, why, when, where, who), which is originated from the discipline of journalism (Mott, 1942). The 5Ws method is a basic formula for getting the full story or seeing the big picture on any subject under investigation. The principle underlying these check-list questions is that each question should elicit a factual answer - facts that are necessary to include in a report for the report to be considered complete. Similarly, the effective implementation of strategies to strengthening knowledge asset base requires a simple but comprehensive check-list that the $6 \mathrm{~K} 1 \mathrm{C}$ framework offers.

Know-where and know-when are investigated at the first step of the strategic planning process: while the vision is being developed. The vision simply shows where we want to head with our plans. This gives a direction towards the desired future. Knowing-where is becoming increasingly important in a resilient and dynamic knowledge economy. Where things are best done or located? Where we get things to happen? Where are the clusters or nodes of knowledge assets accumulated? The levers of change are often reinforced or reached to a critical mass in two types of places. The first type is knowledge community precincts favourably located in inner city areas. Knowledge community precincts (i.e., One-North Singapore, 22@bcn Barcelona and 
Brisbane Kelvin Grove Urban Village) can be regarded as the spatial nexus of KBUD that chiefly refers clustering of R\&D activities, high-tech manufacturing of knowledge-intensive industrial and business sectors linked by mixed-use environment including housing, business, education and leisure within an urban-like setting. The working definition of such areas differs from country to country (i.e., high-tech cluster, knowledge/innovation cluster, science/technology hub and digital village), more or less indicating a clustering of high-tech enterprises with a commercial mix of urban life and culture (Yigitcanlar et al., 2008d). The second type is the emerging knowledge-based cities (i.e., Austin, Melbourne and Helsinki) as a functional city-region for knowledge community precincts. These cities accommodate high quality urban services (i.e., high quality residential areas, cultural districts, recreational facilities and connectivity to global air transport networks) and a diversified economic base including extensive supplier and distribution networks and specialised services. Additionally, knowledge workers, primary sources of intellectual capital, prefer those inspiring cities with a thriving cultural life, an international orientation, and high levels of social and cultural diversity (Baum et al., 2007; Yigitcanlar et al., 2007).

Figure 3 The $6 \mathrm{~K} 1 \mathrm{C}$ framework associated with strategic planning and asset management process

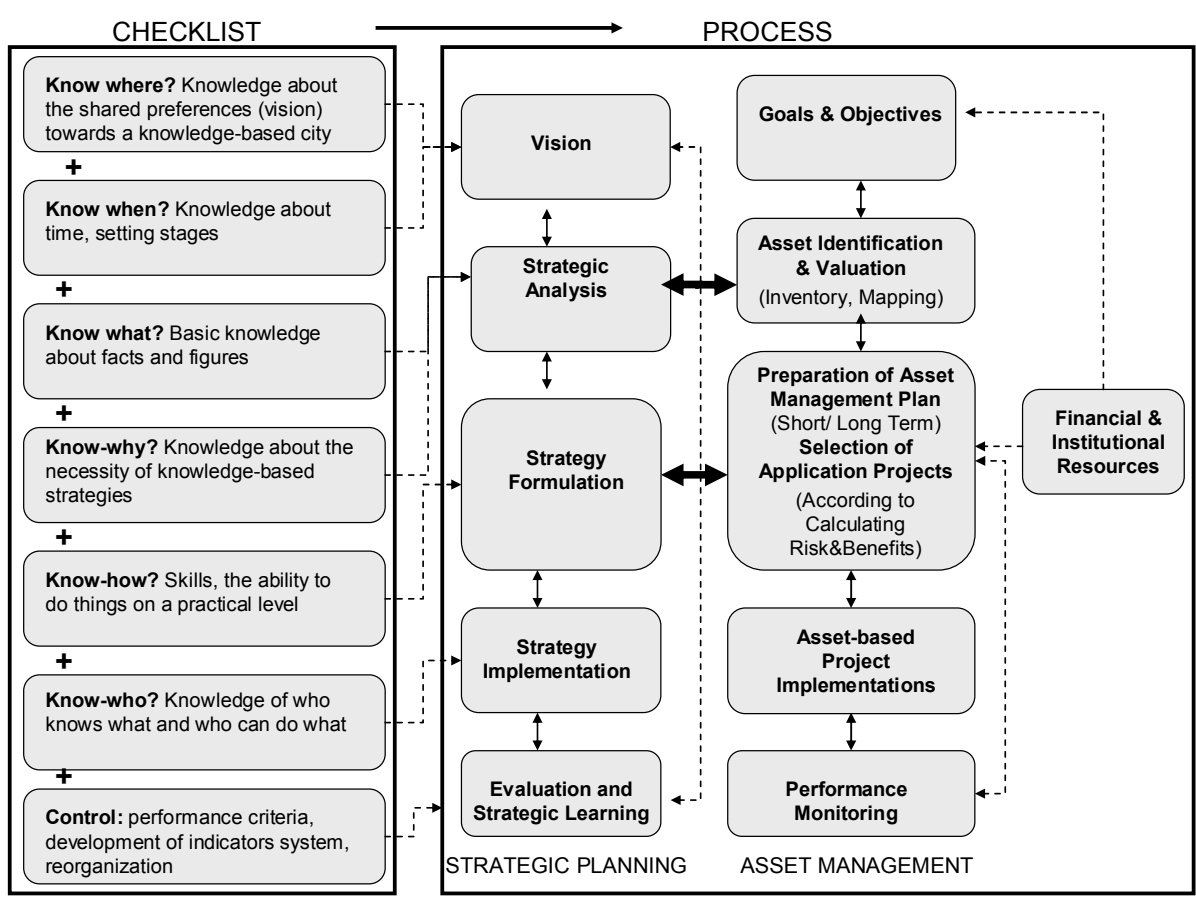

Know-when outlines the timing of the conceived future directed by visioning. In a knowledge-based economy being first to create and innovate is highly critical for firms as well as competing city-regions. This requires the prediction and management of change and making timely adjustments for the conceivable future. India's and Ireland's recent success in knowledge intensive service industries laid their conscious investment in human capital that requires readjustment of human capital to the needs of knowledge-based economy and society within a careful time plan (Heeks and Nicholson, 
2002; Velibeyoglu, 2008). In this sense, know-where and know-when resembles a knowledge about the city's direction towards a knowledge-based city in a conceived time plan.

Know-what and know-why are basically related to the second step of the strategic planning process: strategic analysis. Once the vision is determined, it is followed by the stage of strategic analysis illustrating the internal and external situation assessments (i.e., SWOT); the appraisal of differences between actual and desired states (i.e., gap analysis); and the comparative assessment against potential competitors (i.e., benchmarking). Know-what refers to knowledge about facts and figures that are assumed to provide the solid basis of a vision. This refers to knowledge about the foundations, quality and content of knowledge asset base of city-regions. A recent study by Van Winden et al. (2007) outlines these foundations for knowledge-based cities. They found that basic dimensions like knowledge base, economic base, socio-cultural base, quality of life and place, urban diversity, accessibility and connectivity, and social equity have prime importance for cities to declare themselves as knowledge-based cities. Therefore, know-what simply asks city-regions to what extent they are capable of achieving the basic foundation stones of knowledge-based cities.

Know-why refers to understanding the wider context or the big picture (i.e., knowledge about the natural world, society and human mind) and the vision. Many of us, for example, do not question of daily routine at work. Overspecialisation of modern life has left little room to people to explore the purpose of doing things. The question of know-why gives organisations or city administrations a basic sense of purpose of doing things. For example, knowing-why helps organisations to understand why strategic planning is important and why the process and procedures are becoming increasingly knowledge-based. It helps city administrations in being aware of how to cope with the change (both internal and external) and determining the kind of strategic analysis they need to undertake.

Know-how is associated with the strategy formulation that is the third step of strategic planning process. Strategies depend on goals and objectives and a strategy indicates how that goal or objective will be realised. Know-how simply means the knowledge of how to get things done. In economic terms, know-how refers to skills, the ability to do things on a practical level. It is a form of explicit knowledge (i.e., policies, procedures, formulas or processes) that is transferable (and easily replicated) and contributes to efficiency. But much of the know-how is still implicit to people and places that constitutes the form of tacit knowledge (Cunha and Selada, 2007). In terms of strategic planning know-how implies practical knowledge about strategies outlining how to achieve given goals and objectives aiming the building and strengthening a knowledge-based city. KBUD strategies are not generic (and explicit) strategies, therefore they need to be tailored suitable for city-regions' own knowledge assets. The more endogenous, innovative and participatory the KBUD strategy is, the more successful the outcomes are. In such a process the specifics of the demand side should be taken into account too. The process should not be prescriptive, and should be adapted to meet the requirements of the individuals, and social and business communities.

Know-who refers to knowledge of who knows what and who can do what, and links with the strategy implementation step of the strategic planning process. New forms of capitalism and technological innovations have diminished the significance of national borders and have deepened the interrelations between countries, cities, communities and 
firms. This brought a new strategy agenda into the play and widened the range of actors involved in the strategic planning processes, with new alliances and stakeholder partnerships. Different levels of governments are encouraged to work together (i.e., multi-level governance) and in partnership with actors (i.e., public-private-academic partnerships) in diverse positions in the economy and civil society. Therefore, the organisational dimension of strategic planning involves collaborative planning through networking and management of stakeholders. Stakeholder management is considered as important as their active collaboration. Not all of the collaborative processes are strategic, only the ones that accommodate the strategy features in both of their processes and plans are the strategic ones. A recent example of multi-stakeholder collaboration in managing knowledge-based assets is the triple-helix model (Etzkowitz and Leydesdorff, 2000). At its essence triple-helix is a partnership between the industrial, academic and governmental communities which recognises the differing goals and stakeholder communities of the three groups but stresses the common interest of those groups to provide value to the societies in which they reside. Know-who is the key for mapping and sustaining stakeholder commitment. The process is not easy and requires careful stakeholder management and strategic change from government to governance.

Control links with the evaluation and strategic learning phase of the strategic planning process. Control includes measures like performance criteria, development of indicators and continuous monitoring of outcomes. Strategic learning complements control and outlines that understand and respond to the lessons organisations learn from both formal evaluation and more informal monitoring. Strategic learning also contributes to strategic analysis based on experience and lesson drives from evaluation process (see Figure 3). Although monitoring of outcomes and learning from evaluation is necessarily a positive thing, Mintzberg (1993, p.33) warns organisations to be aware of the illusion of control by stating: "An obsession with control leads to all kinds of behaviours... One is aversion to risk, which means a reluctance to consider truly creative ideas and truly quantum changes, both of whose effects are unpredictable and so beyond formal planning. Another is conflict with the subjects of the planning, who do not appreciate their own loss of control. Planners may see their procedures as merely bringing order and rationality - in effect coordination - to decision making. But coordination is control."

\section{Conclusions}

The research reported here highlights a new logic of networked and knowledge-based economy, which is highly selective and exclusionary. Hence, there is a need for a balancing mechanism for knowledge-based development of city-regions to continue being competitive and sustainable in the long run. The increasing importance of asset mapping and management brought the question of 'how to best manage city-regions' valuable tangible and intangible assets while pursuing a KBUD'. To address this issue, in this paper we introduced a new framework called the $6 \mathrm{~K} 1 \mathrm{C}$ framework that is potentially useful in assessing the tangible and intangible assets of city-regions.

In contrast to static and rigid regulatory tools, the $6 \mathrm{~K} 1 \mathrm{C}$ framework is a simple but effective planning tool that is essential for city-regions coping with the challenges and new ambitious goals of the knowledge-based economy. These challenges and ambitions include: managing the growing complexity of networked and knowledge-based economy, dealing with the rising uncertainty of spatial trends and finding a solution for new 
interdependencies of the knowledge society. The $6 \mathrm{~K} 1 \mathrm{C}$ framework allows city administrations to follow the logical steps in tackling those issues. It also provides coordination and control of all strategic actions and hence contributes to the efficiency in the decision-making process of public service organisations.

Articulation of strategic planning with a knowledge-based check-list system (i.e., the $6 \mathrm{~K} 1 \mathrm{C}$ framework) is vital for the sustainable accumulation of KBUD. However, the proposed $6 \mathrm{~K} 1 \mathrm{C}$ framework still needs to be further developed as a strategic decision-making mechanism mainly focusing on: harnessing tangible and intangible assets of city-regions; realising synergies between public, private and academic spheres; orienting new knowledge-based activities to support shared goals; and concerning widely accepted values, while strongly supporting openness and diversity. Lastly, the $6 \mathrm{~K} 1 \mathrm{C}$ framework has recently been developed and needs to be piloted on a number of case studies for testing the framework so as to see how successful the model is in assessing urban strategies and policies targeting the strengthening of tangible intangible asset base of city-regions. Therefore, further empirical research on the implementation of the $6 \mathrm{~K} 1 \mathrm{C}$ framework is needed to be undertaken.

\section{References}

ARC (2004) Appalachia, Report for Appalachian Regional Commission, Washington, DC.

Baum, S., Yigitcanlar, T., Horton, S., Velibeyoglu, K. and Gleeson, B. (2007) 'The role of community and lifestyle in the making of a knowledge city', Griffith University, Brisbane.

Benneworth, P. and Hospers, G. (2007) 'Urban competitiveness in the knowledge economy: universities as new planning animateurs', Progress in Planning, Vol. 67, pp.105-197.

Boisot, M. (1999) Knowledge Assets: Securing Competitive Advantage in the Information Economy, Oxford University Press, London.

Carrillo, F. (2002) 'Capital systems: implications for a global knowledge agenda', Journal of Knowledge Management, Vol. 6, No. 4, pp.379-399.

Carrillo, F. (2004) 'Capital cities', Journal of Knowledge Management, Vol. 8, No. 5, pp.28-46.

Carrillo, F. (Ed.) (2006) Knowledge Cities, Butterworth-Heinemann, New York.

Castells, M. (2000a) 'Urban sustainability in the information age', Cities, Vol. 4, No. 1, pp.118-122.

Castells, M. (2000b) The Rise of the Network Society the Information Age: Economy, Society and Culture, 2nd ed., Vol. 1, Blackwell Publishing, New York.

Cities Alliance (2007) Understanding Your Local Economy, Cities Alliance, Washington, DC.

Cunha, I. and Selada, C. (2007) 'Innovation hubs' as instruments of urban and regional policy', 1st International Seminar on Regional Innovation Policies, INTELI, Portugal.

ESA (1995) 'European system of national and regional accounts', Eurostat, Chpt 7, available at http://circa.europa.eu/irc/dsis/nfaccount/info/data/ESA95/en/esa95en.htm.

Etzkowitz, H. and Leydesdorff, L. (2000) 'The dynamics of innovation: from national systems and 'mode 2' to a triple helix of university-industry-government relations', Research Policy, Vol. 29, No. 2, pp.109-123.

Filipo, J. (1988) 'On the intangibility of services', The Service Industries Journal, Vol. 8, No. 3, pp.286-293.

Ford (2004) Building Assets to Reduce Poverty and Injustice, Ford Foundation, New York.

Friedmann, J. (2002) The Prospect of Cities, University of Minnesota Press, Minneapolis.

Friedmann, J. (2005) 'Cities unbound: the intercity network in the Asia-Pacific region, management of social transformations - MOST', Discussion Paper Series - No. 23, UNESCO. 
Friedmann, J. (2006) 'The wealth of cities', 3rd World Urban Forum, Vancouver, Canada.

Gonzalez, M., Alvarado, J. and Martinez, S. (2005) 'A compilation of resources on knowledge cities and knowledge-based development', Journal of Knowledge Management, Vol. 8, No. 5, pp.107-127.

Graham, S. (2004) 'Constructing premium network spaces', in R. Hanley (Ed.): Moving People, Goods, and Information in the 21st Century, pp.225-244, Routledge, London.

Healey, P. (2005) 'Network complexity and the imaginative power of strategic spatial planning', in L. Albrechts and S. Mandelbaum (Eds.): The Network Society: a New Context for Planning?, Routledge, New York.

Heeks, R. and Nicholson, B. (2002) 'Software export success factors and strategies in developing and transitional economies', Development Informatics Working Paper Series, Working Paper No. 12, University of Manchester.

Jabareen, Y. (2006) 'Sustainable urban forms: their typologies, models, and concepts', Journal of Planning Education and Research, Vol. 26, pp.38-52.

Jonas, A. and Ward, K. (2007) 'There's more than one way to be 'serious' about city-regions', International Journal of Urban and Regional Research, Vol. 31, No. 3, pp.647-656.

Kaplan, R. and Norton, D. (2004) Strategy Maps: Converting Intangible Assets into Tangible Outcomes, Harvard Business School Press, Boston.

Knight, R. (1995) 'Knowledge-based development: policy and planning implications for cities', Urban Studies, Vol. 32, No. 2, pp.225-260.

Knight, R. (2008) 'Knowledge based development: the challenge for cities', in T. Yigitcanlar, K. Velibeyoglu and S. Baum (Eds.): Knowledge-Based Urban Development: Planning and Applications in the Information Era, pp.13-25, Information Science Reference, Hershey, PA.

Lee, N. (2008) Ideopolis Driver 2: Building on What's There: What Cities and Policymakers Can Learn from Endogenous Growth and the New Economic Geography, The Work Foundation, London.

Lever, W. (2002) 'Correlating the knowledge-base of cities with economic growth', Urban Studies, Vol. 39, No. 5/6, pp.859-870.

Malhotra, Y. (2003) 'Measuring knowledge assets of a nation: knowledge systems for development', Research Paper delivered at the United Nations Advisory Meeting of the Department of Economic and Social Affairs, United Nations Headquarters, New York.

McCann, J. (2007) 'Inequality and politics in the creative city-region: questions of livability and state strategy', International Journal of Urban and Regional Research, Vol. 31, No. 1, pp.188-196.

Mintzberg, H. (1993) 'The pitfalls of strategic planning', California Management Review, Fall, pp.32-47.

Moser, C. (2006) 'Asset-based approaches to poverty reduction in a globalized context', Background paper for workshop entitled 'Asset-based Approaches to Poverty Reduction in a Globalized Context', Brookings Institute, Washington DC.

Mott, F.L. (1942) 'Trends in newspaper content', Annals of the American Academy of Political and Social Science, Vol. 219, pp.60-65.

Reichert, S. (2006) 'The rise of knowledge regions: emerging opportunities and challenges for universities', European University Association, Brussels.

Rowley, D.J., Lujan, H.D. and Dolence, M.G. (1997) 'Strategic change in colleges and universities: planning to survive and prosper', Jossey-Bass, Inc., San Francisco, CA.

Scott, A. (2000) 'Globalization and the rise of city-regions', European Planning Studies, Vol. 9, No. 7, pp.813-826.

Scott, A., Agnew, J., Soja, E. and Storper, M. (2001) 'Global city-regions: an overview', in Scott, A. (Ed.): Global City Regions, Oxford University Press, New York.

The World Capital Institute and Teleos (2007) Most Admired Knowledge City - MAKCi-Awards, MAKCi Framework, Monterrey, Mexico. 
US Department of Transportation (1999) Asset Management Primer, US Department of Transportation Federal Highway Administration Office of Asset Management, Washington, DC.

Van Winden, W. and van den Berg, L. (2004) 'Cities in the knowledge economy', European Institute for Comparative Urban Research, Rotterdam.

Van Winden, W., Van den Berg, L. and Pol, P. (2007) 'European cities in the knowledge economy: towards a typology', Urban Studies, Vol. 44, No. 3, pp.525-549.

Velibeyoglu, K. (2008) 'Urban ICT policies for Turkish local governments: the case of Yalova IT City', in Bucher, U. and Finka, M. (Eds.): The Electronic City, Berliner Wissenschaftsverlag BWV, Germany.

Vigar, G., Graham, S. and Healey, P. (2005) 'In search of the city in spatial strategies: past legacies', Future Imaginings, Vol. 42, No. 8, pp.1391-1410.

Wakefield, K.L. and Blodgett, J.G. (1999) 'Customer response to intangible and tangible service factors', Psychology \& Marketing, Vol. 16, No. 1, pp.51-68.

While, A., Jonas, A. and Gibbs, D. (2004) 'The environment and the entrepreneurial city', International Journal of Urban and Regional Research, Vol. 28, No. 3, pp.549-569.

Yigitcanlar, T. (2008) 'Knowledge-based development of creative urban regions: global perspectives for local actions', The Knowledge International Week, Ibero-American Community for Knowledge Systems, 29-31 Oct 2008, Manizales, Colombia, pp.305-324.

Yigitcanlar, T. and Velibeyoglu, K. (2008) 'Knowledge-based urban development: local economic development path of Brisbane, Australia', Local Economy, Vol. 23, No. 3, pp.195-207.

Yigitcanlar, T., Baum, S. and Horton, S. (2007) 'Attracting and retaining knowledge workers in knowledge cities', Journal of Knowledge Management, Vol. 11, No. 5, pp.6-17.

Yigitcanlar, T., O'Connor, K. and Westerman, C. (2008a) 'The making of knowledge cities: Melbourne's knowledge-based urban development experience', Cities, Vol. 25, No. 2, pp.63-72.

Yigitcanlar, T., Velibeyoglu, K. and Baum, S. (Eds.) (2008b) Knowledge-Based Urban Development: Planning and Applications in the Information Era, Information Science Reference, Hershey, PA.

Yigitcanlar, T., Velibeyoglu, K. and Baum, S. (Eds.) (2008c) Creative Urban Regions: Harnessing Urban Technologies to Support Knowledge City Initiatives, Information Science Reference, Hershey, PA.

Yigitcanlar, T., Velibeyoglu, K. and Martinez-Fernandez, C. (2008d) 'Rising knowledge cities: the role of urban knowledge precincts', Journal of Knowledge Management, Vol. 12, No. 5, pp.6-17. 